\title{
MODERN DÜNYADA MANEVI BİR ARAYIŞIN ROMANI: BİRDENBİRE (SADIK YALSIZUÇANLAR)
}

\section{Zübeyde ŞENDERIN'1}

\begin{abstract}
Özet
Son dönem Türk öykü ve romancılığının önemli isimlerinden biri olan Sadık Yalsızuçanlar, 1962 ylında Malatya'da dünyaya gelmiştir. İlk ve orta öğrenimine Malatya'da devam eden yazar, lise öğrenimini ise Hatay Dörtyol Deneme Lisesinde tamamlamıștır. Hacettepe Üniversitesi Türk Dili ve Edebiyatı Bölümünden 1983 yllında mezun olmuştur. Ardından Türkiye Radyo ve Televizyon Kurumunda (TRT) yardımcı prodüktör olarak 1987 yllında başladığı memuriyet yaşamını 2010 yılında emekli olarak tamamlamıştır. Yazarın ilk edebî yayını, Yeni Asya Gazetesi’nde yayınlanan "Ana” adlı öyküsüdür. Yayınlanan ilk kitabı ise Şehirleri Süsleyen Yolcu'dur (1986). Yazarın başlıca edebî üretimi öykü türünde olmakla birlikte roman, masal, araştırma, inceleme, deneme, derleme, söyleşi ve çeviri gibi çok değişik türlerde çok sayıda eser vermiştir. Tasavvufa dayalı manevi bir olgunlaşma süreci Yalsızuçanlar'ın hemen hemen bütün edebî metinlerinin başlıca temasını oluşturmaktadır. Birdenbire (1912) adlı romanı da bu temanın merkezde olduğu eserlerinden biridir. $\mathrm{Bu}$ romanda Mustafa adlı bir gencin, gündelik yaşamı eşliğinde, iç dünyasında yaşamakta olduğu manevi değişim ve olgunlaşma süreci anlatılmaktadır. Romanı farklı kılan çağdaş dünyanın karmaşası içinde bunalan çağdaş bir gencin manevi bir arayış ve ilerlemeye talip olmasıdır. Bu makalede romanın anlatıcı, zaman, mekân, şahıs kadrosu gibi yapısal unsurları ile romanın tematik örgüsü arasındaki ilişki üzerinde durulmuştur. Ayrıca romanın ana teması olan manevi arayış ve olgunlaşma kavramlarının ele alınış biçimi çözümlenmeye çalışılmıştır.
\end{abstract}

Anahtar Kelimeler: Tasavvuf, olgunlaşma, çă̆daş dünya, birey.

\section{A NOVEL OF SPIRITUAL PURSUIT IN THE MODERN WORLD: BÍRDENBÍRE} (SADIK YALSIZUÇANLAR)

\begin{abstract}
Sadık Yalsızuçanlar, a prominent name among the latest Turkish story and novel writers, was born in Malatya in 1962. After completing his primary education and most of his secondary education in Malatya, he graduated from Dörtyol Deneme High School in Hatay. Afterwards, he graduated from the Department of Turkish Language and Literature at Hacettepe University in 1983. He retired from his job as a civil servant in 2010, the title he gained as an assistant producer for the Turkish Radio and Television Corporation (TRT) in 1987. His first literary work was a story entitled "Ana" published in Yeni Asya Journal. His first published book was Şehirleri Süsleyen Yolcu (1986). His primary interest has been in stories, but he has written various works such as novels, fables, researches, reviews, essays, compilations, conversations and translations. A spiritual maturation process based on Sufism constitutes the main theme of most of his literary works. His novel, Birdenbire (2012), is one of his works based on this theme. This novel tells about a boy, Mustafa, who experienced his spiritual change and maturation process in his inner world and his life story. What makes this novel different is the narration of the life of a contemporary young who follows a spiritual path and is interested in spiritual development. This paper examines the relation between the novel's structural elements (narrator, time, place and characters) and its thematic pattern. It also describes the literary treatment of spiritual pursuit and maturation, the novel's main theme.
\end{abstract}

\footnotetext{
$1 \quad$ Yrd. Doç. Dr., Kırıkkale Üniversitesi, Fen Edebiyat Fakültesi, Türk Dili ve Edebiyatı Bölümü, zubeydesen@kku.edu.tr 
Modern Dünyada Manevi Bir Arayışın Romanı: Birdenbire (Sadık Yalsızuçanlar) / Z. Şenderin (52-62. s.)

Keywords: Sufism, maturation, modern world, individual.

\section{Giriş}

Sadık Yalsızuçanlar'ın hemen hemen bütün öykü ve romanlarının ana tematik eksenini tasavvufi bir bakıșla hayatı ve bireyi değișik cephelerden irdeleme olușturmaktadır. ${ }^{2}$ Tasavvufi düşüncenin maddi dünyayı manevi ve soyut perspektiften anlamlandırmaya dayanan yapısı, Yalsızuçanlar'ın öykü ve romanlarını hem biçim hem de içerik açısından özgün bir yapıya kavuşturan temel noktadır3. Bu bağlamda, edebî üretiminde soyutlama ve sembolik / mecazi / imgesel dil geliștirme, temel düşünsel dayanağı olan tasavvufun doğal ve kaçınılmaz bir izdüşümü olarak eserlerinde yoğun biçimde yer almaktadır. Bu kaynaktan beslendiği için de "mecaz dünyası İslâmî ve millidir." (Kabaklı, 2002: 686). Tasavvuf mirasını yaratan şahıs ve eserler de metinlerinde sık sık alıntılanmakta, bu da eserlerinin metinler arası ilişki boyutunu son derece zenginleştirmektedir. Tasavvufun yerli ve aynı zamanda evrensel mirası yazarın başlıca ilgisini teşkil ettiğinden kimi romanlarında Muhyiddin-i Arabî, Ebu'l-Hasan Harakanî, Niyazî-i Mısrî gibi büyük mutasavvıfların yaşamöykülerini romanlaştırma çabası içinde olduğu da görülmektedir.

Öykü ve romanlarının klasik kalıpların dışında bir biçimsel yapıya sahip olmasında yine tasavvufi hayat ve birey algısının etkisi olduğu görülmektedir. Sürekli aşkın bir gerçeklik peşinde koşması, yazarı, bu gerçekliği mevcut olan dil ve biçim altında anlatabilmenin en uygun yolunu arama çabasına yöneltmiştir. Bu çaba, öykü ve romanlarını klasik yapıların dışına çıkararak kendi ifadesiyle birer "anlatı"ya çevirmiștir. 4 Bu anlatılar ne dıș dünyadan tamamen bağımsız ve ilgisiz, tamamen iç gerçekliğe gömülmüş ne de bütünüyle diş dünyayla meşgul metinlerdir. Tıpkı tasavvufun önerdiği gibi dış dünyayla ilgili ve bu dünyanın içinden aşkın gerçekliğe yol arayan metinlerdir.

\section{Romanın Tahlili}

Birdenbire 5 adlı romanı da Sadık Yalsızuçanlar'ın en dikkate değer ve bilhassa içerik bağlamında tipik eserlerinden biridir. Roman, sayısal bir bölümlendirme ile "111" bölümden oluşmaktadır. Bu bölümler, birkaç sayfadan ya da bir iki satırdan oluşabilmektedir. Her bir bölümün başında "nokta” yer almaktadır. (“.111” gibi). "İşin başı nokta. Sonu nokta. Arası yok zaten.” (s.19) cümlesi de varılmak istenen temel hedefin her șeyin ilkinin ve sonunun "nokta" olduğu ve ancak noktaya ulaşanın yolculuğu tamamlayacağı yolundaki inanca bir göndermedir. Zaten tasavvufta nokta "hakiki birlik, tüm çokluğun ash” (Uludağ, 2012: 279) olarak kabul edilmektedir:

"Noktaya bakıyordum. Baktıkça anlar şimdiye hapsoldu. Bir dem, bir an ve bir nokta oldu. Dem ve an da yok oldu nokta kaldr. Gözlerim yok oldu. İki bir oldu. Bir noktaya girdi. Nokta her şeyi yuttu. Noktadaydım artık. İçine girince fark ettim görünmeyen bir

2 Sadık Yalsızuçanlar, kendisiyle yapılan bir söyleşide eserlerinin tasavvufi içeriğine rağmen sufi olmadığını ve bu anlamda irfan sahibi de olmadığını ifade etmektedir. Fakat hayatı boyunca gerçek bilgiye sahip arifler tanıma şansına sahip olduğunu ve onlar vasıtasıyla manevi dünyaya kitapların ötesinde nüfuz edebildiğini anlatmaktadır. (Harmancı, Köseoğlu, 2012: 30).

3 Sadık Yalsızuçanlar'ın hayatına dair bu kısa bilgi resmî web sitesine dayanmaktadır: http://www.sadikyalsizucanlar.net/eskisite/turkce/hayati.htm (Erişim Tarihi: 30.05.2016).

4 Sadık Yalsızuçanlar bir soruşturmaya verdiği cevapta, başlangıçta öykü, roman, deneme gibi edebî türlerin belli kuralları olduğuna inandığını, fakat zamanla içeriğin kuraldan daha önce geldiğine inanmaya başladığını "söz, kelâm, öykü, her neyse, kuraldan, ölçüden önce geliyor" cümlesiyle ifade etmektedir. En sevdiği metinlerde de "eserin kuraldan önce geldiğini" gördüğünü söylemektedir (2000: 261). Bu ifadeler, edebî metinlerde biçim / öz ilişkisi bağlamında yapılan tartışmaların devamı gibidir. Buna göre Yalsızuçanlar'ın edebî üretiminde “öz"ün "biçim”den önce geldiği ve "biçim”in “öz”̈̈n dayattığı kalıba girmesi gerektiğine dair bir inanca sahip olduğu söylenebilir.

5 Bu incelemede romanın şu baskısı kullanılmıştır: Sadık Yalsızuçanlar (2012), Birdenbire, İstanbul: Timaş Yayınları. Romandan yapılacak bütün alıntılar bu baskıya aittir ve alıntının sonunda yalnızca sayfa numarası verilecektir. 
kandildi o. Hâlâ fark edebiliyordum. Farklı bir biçimde ışıyor, yerine dönüyordu. Bütün kandilleri yutmuş, hepsine sultan olmuştu." (s.9).

Daha ilk bölümde geçen bu cümleler, romanın dairevi bir çizgiyle hareket edeceğini, tematik açıdan başladığı noktaya döneceğini açıkça göstermektedir. Böylece anlatılan insan öyküsüyle varılacak yer, daha ilk bölümde ifade edilmiş olmaktadır.

Romanın adı olan "birdenbire" kelimesinin ise pek çok tasavvufi alt anlamı içinde barındırdığı düşünüldüğü için özellikle seçildiği görülmektedir. $\mathrm{Bu}$ alt anlamlar romanda anlatılan öykünün değişik katmanlarına sinmiştir ve öykü boyunca yeri geldikçe açı̆̆a çıkmaktadır. Romanın ".1" başlı̆̆ını tassıyan ilk bölümü de "birdenbire"nin karşılığına dair izahla başlamaktadır. Buna göre "bir-den-bire"; "Tanridan Tanriya”, "her şey O'ndan ibaret", "zamansızhk / bir tek an", "mekânsızhk", "bütün bir varlık âlemi / oluş süreci”, "seyr ü sülûk / kendini bulma", "vahdet", "sonsuzluk" gibi anlamlar içermektedir. Yazar da Mustafa adlı kahramanının yaşam öyküsünü "birdenbire"nin bütün alt anlamlarının yaşandığı sayısız örnekten bir örnek olarak anlatmaktadır. Çünkü "birdenbire" yazar açısından varlık alanında yaşanan her şeyi açılayan anahtar kavram hükmündedir. Dolayısıyla hemen ilk bölümde karşımıza çıkan "birdenbire" kelimesini tasavvufi anlamda kavramsallaştırma çabası, yazarın hayat / evren / varlık algısını da gözler önüne sermektedir.

Romanda Mustafa'nın çocukluk yıllarından orta yaşlılık dönemine değin geçen hayatı eşliğinde ilerleyen manevi olgunlaşma serüveni anlatılmaktadır. Mustafa'nın hayatı -roman boyunca tarihsel bir sıralama ile ilerleyerek anlatılmamakla beraber- kronolojik bir düzlem içinde ana hatlarıyla şöyle özetlenebilir: Mustafa, Aydın’ın Kızılcabölük köyünden bir gençtir. Ev hanımı annesi ve terzi olan babası, çok çalışkan, dindar, kanaatkâr, haram-helal kavramlarına özel bir dikkati olan, mümin / mütevekkil, yoksul insanlardır. Anne, baba, abla, ağabey ve nineden oluşan ailesiyle yoksul fakat manevi açıdan temiz ve besleyici bir çocukluk dönemi geçirmiștir. Mustafa "Anam, babam, dedelerim, ninelerim, medrese müslümanı değil, gönül müslümanıydr." (s.127) derken manevi arayışına yön veren çevrenin din anlayışının genel geçer din anlayışından ayrımına özellikle dikkati çekmektedir. "Hakikati bilenlerin yaşadığı bir çevrede doğmak büyümek, onlarn kültürüyle hemhâl olmak elbette bir lutf-ı ilahidir. Ben de hakikati sessiz sedasız yaşayan bir topluluk içinde doğdum, büyüdüm, yaşadım" (s.347348) cümleleriyle daha küçük yaşta başlayan arayışının aile ve çevre ile nasıl desteklendiğini ifade etmektedir. Mustafa, çocukluk ve ilk gençlik yıllarına tesir eden ve yine bir yönüyle manevi arayışında da etkili olan bir gönül macerası yaşamış, Elif adlı bir kızı sevmiş fakat reddedilmiştir.

Yaşamak için sürekli bir mücadele içinde olan, manevi açıdan zengin maddi yönden yoksul bu ailede ağır ve uzun süren bir hastalık devresi geçiren babanın vefatının ardından ailenin geçim yükü Mustafa'nın omuzlarına binmiş, bu ağır yük nedeniyle onun için okumak bir müddet imkânsız hale gelmiştir. Fakat ayakta kalma mücadelesine devam eden Mustafa lise tahsilini Denizli'de, üniversite tahsilini de Balıkesir'de Necatibey Eğitim Fakültesi'nde tamamlamıştır. Daha sonra Gazi Üniversitesi'nde asistan olarak göreve başlamıştır. Akademik hayatı da manevi yürüyüşüne paralel olarak tasavvufi konular üzerine çalışmakla geçmektedir. Fakat akademik hayat içinde aradığını bulamamıştır. Akademinin "insanın içini çürüten bir yer" (s.114) olduğunu düşünmektedir. Hemen herkes küçük maddi kazançlar peşinde koșmaktadır. Öğrenciler ilgisiz ve sevgisizdir. Kendini adadığı ilme daha doğrusu aşka "talip yok"tur (s.125). Tasavvufun sunduğu hakikat ve gizemli dil yeni nesle çok uzaktır. Tasavvufi "mecazlar" (s.237) somut gerçekliğe son derece bağlı bu nesil için hiç bir şey ifade etmemektedir. Çalışma alanı kendi arayışına denk düşse de çevresini dolduran insanlar bu dünyadan çok uzaktadır. Akademide gerçekten "kirlenmeden kalan" (s.114) çok az insan vardır. Mustafa bu hayat macerası içinde Ebru adlı bir hanımla evlenmiş, Ahmet adlı bir oğlu, Nezahat adlı bir kızı olmuştur.

Suradan görünen bu hayat mücadelesi içinde, güncel / siyasi olaylar, mekânlar, nesneler eşliğinde kendi dervişane yolculuğunu da devam ettirmiştir. 
Mustafa'nın iş, aile, okul ve meslek hayatı eşliğinde dış dünya ile kurduğu doğrusal ilişki, kendini keşfetmeye yönelen iç dünyaya yönelişle iç içe anlatılmaktadır. Bu iki hayat tamamen ayrı düzlemlerde değil, birbirini değiştiren ve dönüştüren bir ilişki içinde sunulmaktadır. Öyle ki Mustafa'nın manevi yürüyüşü, gündelik hayatının içinde, hatta gündelik hayatının beslemesiyle gerçekleşmektedir. Mustafa dört koldan manevi ilerleyișine destek bulmaktadır: Aile çevresi, çocukluk yıllarından itibaren ona rehberlik eden mürşidler, İslam coğrafyasının büyük mutasavvıfları ve rüyalar. Nitekim Mustafa o manevi dünyayı teneffüs eden anne-baba ve büyükanne, büyükbaba figürlerinin bulunduğu bir evde dünyaya gelmiştir. Daha çocuk yaşta ilk manevi rehberi Necat Ağbi'si elinden tutmuş, yol boyunca da Arif, Mahrem ve Hafiz Ağbiler, Yakup Aziz gibi “diriler” sözleriyle, Yunus Emre, Niyazî-i Misrî, Kemâli Dede, Ganem Dede, Yaman Dede, Yamalı Dede, Hacı Bayram-ı Velî, Şaban-ı Velî, Hacı Bektaş-ı Velî, Hallac1 Mansur, İbrahim Edhem, Aziz Mahmut Hüdayi, Abdal Musa, Kaygusuz Abdal, Pir Sultan Abdal, Muhyiddin-i Arabî, Ebu'l-Hasan Harakanî, Bayezid-i Bistami gibi bedenen “ölüler” yazı ve menkıbeleriyle manevi mürşidler olarak Mustafa'nın yolunu aydınlatmışlardır. Ayrıca birkaç meczup velinin hikâyesi de romanda anlatılmaktadır. Deli Tahsin, Halil İbrahim, Deli Ahmet, vb. Elbette tasavvufta bilginin aktarımında önemli bir vasıta olan "rüyalar" da Mustafa'ya manevi durumunu haber veren bir vasıta olarak sık sık karşımıza çıkmaktadır. "Kiși düşünde ne görürse görsün kendini görür. Rüyalar ayna mıdır? Aynadır. Ayna sırlı mıdır? Strlanmıştır." (s.231) derken rüyaların sembolik bir dil üzerinden kişiye içinde bulunduğu ruhsal durumu haber veren yönüne işaret edilmektedir. "Düşte görünen kişinin kendisidir. Ne görürse görsün, gördüğü kendi deneyimleridir” (s.232) cümlesi, rüyalar vasitasiyla yolcuya, içinde bulunduğu ruhsal / manevi pozisyonun, bulunduğu durağın ve gideceği yolun gösterildiğine vurgu yapmaktadır.

Dolayısıyla Mustafa'nın hayatı zahir / bâtın olarak iki ayrı düzlemde ilerlemektedir. Gündelik hayatın altında manevi bir ilerleyiş bulunmaktadır. Dış dünya da bu ilerleyişi sürekli desteklemektedir. Mustafa'nın yolculuğu, geleneksel mürşit / mürit ilişskisinin dış yapı itibariyle değiştiğinin, artık seyr ü sülukün telaş içindeki şehirli insanlara farklı yollardan yaptırıldığının göstergesi olması açısından önemlidir. Mustafa mürşidinden söz ederken “... bir zamanlar ariflerin uzunca bir sürede, erkanıla yaşadıklar vahdet macerasın, bize farkh biçimde yaşatmaktaydl." (s.274) derken buna işaret etmekte, "Bugün Ahmed benim, diyordu Zamanın Sahibi. Bugün Anka benim. Gün benim günüm. Erkanı değiştirir, herkese farkh uygulayabilirdi." (s.274) diyerek içinde bulunulan zamana bağlı olarak manevi öğretim metodunun da değiştiğine vurgu yapmaktadır.

Buna göre romanın ana teması, gündelik / çağdaş dünyanın kendine mahsus sıkıntıları içinde hayat mücadelesini yürütmeye çalışan Mustafa adlı gencin manevi olgunlaşma yolculuğudur.

Roman, birinci tekil şahıs "ben anlatıcı", dolayısıyla da kahraman bakış açısı ile kaleme alınmıştır. Teknik olarak "ben anlatıcı"nın yazar açısından bazı kısıtlayıcı yönleri bulunmakla birlikte, bu anlatıcı okurun kahramanın ruh dünyasıyla doğrudan bir ilişki kurarak tam bir özdeşleşme yaşamasını sağlaması noktasında avantajlı bir anlatıcı tipidir. Bu anlatıcı tipinin seçilmesi, yazarın olayları, olguları ve durumları özellikle kahramanın bakış açısından, onun gözlerinden aktarmayı tercih ettiğini göstermektedir. Elbette çağdaş dünyanın kendine mahsus koşulları içinde, bütün hayatı manevi bir arayış ve tamamlanma arzusuyla geçen birinin hayatını anlatırken okuru (muhtemelen yadsıyacağı böyle bir ruhsal çabanın öznesi olan) kahramanın olgunlaşma sürecine ortak edebilme çabasının, yazarı bu anlatıcı tipine ve bakış açısına yönelttiği tahmin edilebilir. Nitekim bu anlatıcı tipinin ve bakış açısının okur / kahraman arasındaki özdeşleşmeyi kurabilme açısından oldukça kullanışlı olduğu açıtıtır. Çünkü okur açısından istenen dışardan, tarafsız bir seyir değil, en azından belli anlarda bu arayışa anlam vererek temas etmesini sağlamaktır.

Romanda zaman / mekân / şahıs kadrosu gibi diğer unsurlar da bazı postmodern metinlerle karşılaştırıldı ̆̆ında tespit edilebilir belirginliktedir. Nitekim romanda geçen olaylar, 1970'li yıllardan başlamakta, iki binli yıllara değin sürmektedir. Fakat yine de anlatıya dayalı edebî türlerin bu temel yapısal unsurlarının bir karmaşa içinde sunulduğu da açıktır. Bu karmaşanın yazarın varlık ve hayat algısından kaynaklanan bilinçli bir alt üst ediş olduğu görülür. Çünkü 
yazar, postmodern metinlerin kaotik evren algısından kaynaklanan karmaşasını, gizli / aşkın bir gerçekliğin izdüşümü olarak görmektedir. Bu durum yazarın bu unsurların her birini bilhassa kronolojiyi parçalayarak sunmasının temel nedenidir.

Romanın Mustafa'nın hayatı üzerinden ifade etme arzusu içinde olduğu varlık felsefesi, İslam'ın tasavvufi yorumuna dayanmaktadır. Bu yoruma göre gerçeküstü / aşkın evrenden gelen bilgi, bütün görünür / reel varlık âleminin sürekli bir değişim hâlinde olduğunu haber vermektedir. Aklın ve gözün algıladığı her şey, her an değişim halindedir. Bu âlem içinde yaşayan ve kendini hem tanımlayıp hem de gerçekleştirme çabası içinde olan birey, dış dünyada karşılaştığı unsurlar vasıtasıyla hayat üzerine bir düşünce ve inanç geliştirmektedir. Oysa dış dünyayı tanımlanabilir kılan ve belli inançlar geliştirilmesine vesile olan zaman, mekân hatta değişik düzeylerde bağ kurduğumuz insanlar dahi sabit unsurlar değildir. Dolayısıyla reel âlemin ilk vasfı, değişkenlik ve bundan kaynaklanan güvenilmezliktir.

Örneğin zaman, aklın algıladığının aksine doğrusal (kronolojik) bir yapıda bile değildir. Yazar "Hoş zamanın da ardışık olmadığımı öğrendiğimden beri bu söz grubunu isteyerek kullanmıyorum.” (s.15) cümlesiyle Mustafa'nın ağzından, romana yayılan parçalanmış ve düzensiz zaman parçalarının bilinçli bir tercih olduğunu okura duyurur. Buna göre insan hayatını inşa eden her bir küçük zaman adacı̆̆ı, içindeki insan - mekân - olaylarla birlikte "bir an” içinde akıp gitmektedir. Her şey zaten "olup bitmiştir" ya da geçmiş ve gelecekteki her şey "o an içinde olup bitmektedir." Kahraman anlatıcı "Birdenbire oldu bütün bunlar. Bir anda, sonsuz bölünebilir bir zamanin en küçük biriminde. Bir nefesti orası.” (s.8) derken, romanın henüz ilk bölümünde zamanı nasıl algıladığını açıklamakta, "Her şey avcundaymış, şimdideymiş, şu anmış, bir dem imiş her şey." (s.139) cümlesiyle bizatihi kendi hayatının da olmuş ve olacak olanlarla birlikte sadece bir an'dan ibaret olduğunu ifade etmektedir. Bu bir çelişkiyi değil, ilahi bir düzeni işaret etmektedir.

Yazar da bu inanca bağlı kalarak Mustafa'nın hayat parçalarını kronolojik bir düzlemde vermez. Geçmiş ve mevcut zaman iç içe anlatılır ve bir sıra takip etmez. Yazar Mustafa'nın ister çocukluğunu, ister gençliğini, ister olgunluk yaşlarını anlatsın çoğunlukla şimdiki zaman veya geniş zaman ile anlatmayı tercih eder. Bu da, anılar dile getirildiğinde dahi, olaylar anlatılırken gerçekleşiyormuş ya da az önce gerçekleşmiş izlenimi bırakır okurda.

Mekân da bu inancın bir parçası olarak, zaman kavramıyla paralel bir değişkenlikle çocukluk / gençlik / yetişkinlik dönemleri bağlamında süratli bir değişimle sunulur. Romanda Mustafa'nın hayatının geçtiği fiziksel mekânlar elbette adlarıyla anılmaktadır. Çocukluğunun ve gençliğinin geçtiği Aydın'ın Kızılcabölük köyü, lise tahsilini tamamladı̆̆ üniversiteyi tamamladığı Balıkesir, meslek ve aile hayatını sürdürdüğü Ankara ve gidip gördüğü İstanbul, Uşak, Antalya, Düzce, Manheim gibi başka şehirler... Genelden özele gidişle şehirler kadar daha dar ve kapalı kimi mekânların da Mustafa'nın hayatında yer ettiğini gözlemleriz: Osmanefendi Konă̆ı, Kulekapısı Mevlevihanesi, Huzur Eczanesi, Asmalı kahve, Babadă̆, vb. Bu fiziksel mekânların Mustafa'nın hayatının hangi dönemine ait olduğu hemen algılanamayacak bir süratle bazen aynı bölüm içinde dahi sıklıkla değiştiği görülebilmektedir.

Mustafa'nın hayatını geçirdiği bütün bu yerlerin, bedensel varlığını taşıyan fiziksel mekânlar olmalarının ötesinde manevi yolculuğuna zemin teşkil ettikleri de bir gerçektir. Manevi yolculuğu söz konusu olduğunda ise bu mekânlar Mustafa'yı hâlden hâle çeviren irili ufaklı tuzakların ve aşılması gereken engellerin bulunduğu birer oyun alanı gibidirler. Buradan bütün bir dünya hayatının sadece oyun ve eğlenceden ibaret olduğu inancına varılır: "Dünya oyundur. Sahnedeyiz. Oyuncularız isste. Herkes rolünü yapıp gidiyor. Kimse kararmda durmuyor." (s.236). Yaşanılan, gezilen, görülen her yer, yaşamak denilen bu oyunun sahnelerinden ibarettir.

Romanda Mustafa'nın hayatının geçtiği mekânların adı anılsa da, yani Mustafa beden olarak bir yerlerde olsa da, romanın sonuna değin süren manevi arayışına eşlik eden yoğun bir "yerini bulamamışlık" duygusu içinde olduğu da açıkça hissedilmektedir. Bu kuvvetli yersiz yurtsuzluk hissi, bir tür "mekânsızlık" algısı yaratmaktadır. Buna göre Mustafa'nın kendisini tamamen ait 
hissettiği, tamlık duygusunu tattığı fiziksel bir mekân bulunmamaktadır. Sadece mürşid-i kâmilin huzurundayken tam anlamıla bir yerini bulmuşluk ve aidiyet hissi tadabilmektedir. Bu aidiyet duygusu da fiziksel mekânla ilişkili değildir. Mürşid-i kâmilin bulunduğu herhangi bir yer bu hissi verebilmektedir. Aidiyet mekândan kaynaklanmamakta, mürşidin varlığından kaynaklanmaktadır. "Burası ölümün ve göçün dokunamadığı bir yer. Burası yersiz yurtsuzluk. Buraya gelince zamanın, mekânın dışına çıkıyorum. Onu bulunca her şeyi kaybediyorum." (s.284) cümlesi mürşidin huzurunda dünyevi bağlardan kurtulup soyut bir yurda kavuşulduğunu işaret etmektedir.

Dolayısıyla romanda mekân olgusu da diğer tüm unsurlar gibi maddi ve manevi veya zahir ve bâtın olmak üzere iki düzeyde kendini göstermektedir. Fiziksel olarak adı anılan mekânlar ve bu mekânlarda yaşanan manevi değişimler, asıl olanın mekânın maddi varlığı taşıyan fiziksel boyutunun değil, manevi değişime eşlik eden boyutu olduğunu göstermektedir.

Romanda şahıs kadrosu ise oldukça geniş olmakla birlikte başkişi konumunda olan sadece Mustafa'dır. Bütün roman Mustafa'nın maddi ve manevi hayatının değişimi ve gelişimi üzerine kurulmuştur. Dolayısıyla Mustafa duygusal ve ruhsal gelişimi açısından çok boyutlu olarak sunulan, bu yönüyle de karakter olarak inşa edilen belki de tek roman kişisidir. Romanda onun iş, aile, meslek hayatı içinde zaman zaman görünen kişilerden her biri, hayat yolculuğuna eşlik eden yardımcı kişiler hükmündedir. Mustafa'yı kişi kadrosunun merkezine yerleştirdiğimizde, diğer herkesi onun hayatındaki yerleri bağlamında yardımcı kişiler olarak kategorize etmek mümkün görünmektedir. Aile, iş, arkadaş ve meslektaşları ayrı ayrı kalabalıklar hâlinde, kimi daha az kimi daha yoğun bir şekilde Mustafa'nın hayatının akışı içinde yerini almaktadır. Yine bu yardımcı kişilerin her biri bir yönüyle manevi yürüyüşüne de eşlik etmişlerdir.

Romanda Mustafa'nın dışında yer alan kişiler içinde en dikkate değer olanları, manevi ilerlemesine doğrudan katkıda bulunan rehber figürler yani mürşidlerdir. Bunlardan ilki, daha cocukluk yıllarında elinden tutan Necat Ağbi'dir. Onun dışında Arif Efendi, Mahrem Ağbi, Âgâh Ağbi, Hafız Ağbi, Yakup Aziz gibi çocukluk ve gençlik ylllarında ona yol gösteren pek çok kişi bulunmaktadır. Bu kişilerin her biri Mustafa'nın manevi açıdan bir anlayış geliştirme sürecini değişik düzeylerde etkilerler. Fakat onların yanında Yunus Emre, Niyazî-i Mısrî, Kemâlî Dede, Yaman Dede, Ganem Dede, Hacı Bayram, Hacı Bektaş, Kaygusuz Abdal gibi mutasavvıflar da kitapları ve menkıbeleriyle Mustafa'nın daimî rehberleri olarak karşımıza çıkmaktadır.

Mustafa'nın ailesi de dindar insanlardır. Hatta çocukluğunun geçtiği bütün köy, Mustafa gibi bütün hayatını manevi olgunlaşmaya adayacak birinin yeşermesine yardım edecek şekilde manevi iklimi kuvvetli bir yer olarak tasvir edilmiştir. Bütün köylüler ailesi gibi müminmütevekkil, yoksul olmalarına rağmen paylaşmayı bilen ve birbirlerinden emin olan kimselerdir.

Mustafa'nın maddi / gündelik hayatına giren insanlarla ilişkisi herkesinki gibi olumlu / olumsuz değişikliklerle çalkalanırken, manevi yolculuğuna eşlik eden kişiler daima mürşit ve mürit ilişkisi içinde sunulur. Bu durum Mustafa'nın hem kendi hayatında mürşit olarak değer verdiği ve bağlandığı kişilerle ilişkisinde hem de geçmiş yüzyılların mürşitleri ile ilgili anlattığı bazı menkıbelerde karşımıza çıkar. Bu menkıbelerde mürşit ve mürit ilişkisinin nasıl olması gerektiğini anlatan pek çok öğüt yer alır. Bu ilişkinin ilk vasfı mürşide tam bir itaat içinde olmanın gerekliliğidir. Mustafa kendi mürşidiyle ilişkisini anlatırken "Bir kilim gibi eşiğine seriliyorum." (s.137) veya "Eşiğine toprak gibi seriliyorum". (s.137) der. Bu, arzu edilen tam itaati ve teslimiyeti tarif etmektedir. Hatta mürit, hakikati hak etmek için mürşidinin elinde "ölü yıkayıcısının elindeki ölü” (s.277) gibi olmalıdır. Buna göre zahirî hayatında hemen herkesinkine benzer mücadeleler içinde olan mürit, manevi yolculuğunda ancak rehbere tam bir teslimiyetle hedeflediği yere ulaşabilir denilmektedir.

Romanda bazı kişi adlarıyla ilgili bir sembolizasyon olduğu da göze çarpmaktadır. Bu sembolik art anlamlar, Mustafa'nın manevi arayışına göndermeler içermektedir. Örneğin romandaki manevi arayışın öznesi konumunda olan Mustafa'nın adının kelime anlamı "seçilmiş / 
temiz"dir. İlk mürşidi Necat'in kelime anlamı “kurtuluş”tur (s.332). İlk sevgilisi Elif, “Allah'n mutlak tekliği ve birliği”"ni (Uludă̆, 2012: 121) temsil eder. Suretlerin ötesinde yegâne sevgili O'dur. Mustafa'nın ilk sevgilisi Elif de aslında onun başından itibaren tek sevgiliye yöneldiğinin kanitı durumundadir.

Romanda, hemen hemen bütün romanlarda olduğu gibi tasvir, tahlil, özetleme, geriye dönüş, diyalog, monolog gibi anlatım tekniklerinin kullanıldığı görülmektedir. Fakat en çok kullanılan ve romanın tematik yapısı açısından en kullanışlı anlatım tekniğinin metinler arası ilişki olduğu göze çarpmaktadır. Bilindiği üzere tasavvufi arka planı olan bütün romanlarda bu anlatım tekniğ́i sıklıkla kullanılmaktadır. Bu romanda da ayet ve hadislerin yanı sıra önemli mutasavvıfların menkıbelerinden, şiirlerinden de pek çok örnek verilmektedir.

"Eli bütün ellerin üzerinde.” (Fetih Suresi / 10) (s.11); "Dilimdeki düğümü çöz.” (Taha Suresi / 25-28) (s.13); "Gözleri var görmezler, kulakları var duymazlar." (Araf Suresi / 179) (s.256); "Allah her an yeni bir şe'ndedir, yeni bir işte, yeni bir oluştadır." (Rahman Suresi / 29) (s.82); "Onlar nefislerini ilah edindiler." (Furkan Suresi / 43) (s.288); "Bugün dininizi tamamladık." (s.259); "O her an yeni bir işleyiştedir." (Rahman Suresi / 29) (s.210); "Bilenle bilmeyen bir olur mu?" (Zümer Suresi / 9) (s.210); “Tuva vadisine giremeyenlerin papucu ayağından güçlükle çıkıyor.” (Taha Suresi / 12) (s.173) gibi ayet-i kerimelerin tamamına veya bir kısmına işaret eden ifadeler, ayet oldukları çoğunlukla vurgulanmadan, anlatılan duruma gönderme olarak metne iktibas edilmektedirler. Aynı şekilde "Insanlar uykudadır, ölünce uyanırlar." (s.22) gibi hadis-i şerifler de bağlam içinde iktibas edilmektedir.

Romanda metinler arası ilişkinin bilhassa tasavvufi metinlerden kaynaklanan yoğun bir malzemeye dayandığı görülmektedir. Bu ilişki bazen mutasavvıfların adını anma, bazen onlarla ilgili menkıbeler anlatma, bazen eser adları verme şeklinde olmaktadır. Ama mutasavvifların şiirlerinden yapılan alıntılar, en çok karşılaştı̆̆ımız metinler arası ilişkidir: "Gözsüzlere pinhân imiş." (Niyazî-i Mısrî) (s.22); "Ylkıld fikir kalem, yapıldı din ve imanım." (Niyazî-i Mısrî) (s.42); "N’oldu bu gönlüm n'oldu bu gönlüm.” (Hacı Bayram Veli) (s.32); "Geceler ta sabaha dek inletir bu dert beni." (Niyazî-i Mısrî) (s.23); "Kastım budur şehre varam, feryad u figan koparam." (Yunus Emre) (s.78); "Benim ol aşk bahrîsi denizler hayran bana. Derya benim katremdir zerreler umman bana." (Yunus Emre) (s.85); "Ansızı bir şara vardım, o sarı yapılır gördüm, ben dahi yapılır oldum, taş ve toprak arasında." (Hacı Bayram Veli) (s.32); "Ehlini bul o illerin, sarptır geçersin bellerin... Yurtar yalnzz gideni kurt, kaplan ve arslan kamû...” (Niyazî-i Mısrî) (s.252) gibi onlarca dize Mustafa'nın manevi arayışına anbean tercüman olmaktadır. Çünkü şiir içsel bir tecrübeyi aktarmada "aklî açıklamalardan çok daha ileri bir yeterliliğe sahiptir." (Chittick, 2003: 160). Bu nedenle Mustafa "Halimi ancak âşıkların dizeleri anlatabiliyor" (s.75) demektedir.

Dinî ve tasavvufi metinlerin yanı sıra şarkı, türkü, şiir gibi farklı türlerden de yeri geldikçe alıntılar yapılmakta, her bir alıntı din dışı bir kaynaktan geliyormuş gibi görünse de tasavvufi bir açılıma zemin teşkil etmektedir. "Ne hasta bekler sabah, ne taze ölüyü mezar, ne de şeytan bir günahı, seni beklediğim kadar." (Necip Fazıl) (s.71); "Beni kör kuyularda merdivensiz brrakıp evine dönüyor." (Ümit Yaşar Oğuzcan) (s.93) gibi şiirler ve "Bir ihtimal daha var o da ölmek mi dersin." (s.127); "İşte gidiyorum çeşm-i siyahım." (s.127); "Seyreyle güzel kudret-i Mevla neler eyler..." (s.151); "Felek bir gün cana kıyar, sizi kaptan kaba koyar" (s. 223) gibi şarkı, türkü ve ilahiler, Mustafa'nın manevi arayışının izdüşümü olarak alıntılanmaktadır. Çünkü farklı bir dünyadan sesleniyormuş gibi görünen her şey aslında aynı hakikati dile getirmektedir.

Romanda Mustafa'ya yolculuğu boyunca ilham veren kimi tasavvufi metinlerin de adı anılmaktadır. Nezihe Araz'ın Anadolu Evliyaları, Yunus Divan'ı, Niyazî-i Mısrî Divan'ı, Fuzuli Divan'ı, Kemâli Baba'nın Aşk Sizıntıları, Hallac'in Tavasin'i, Filibeli Ahmed Hilmi'nin A'mâk-

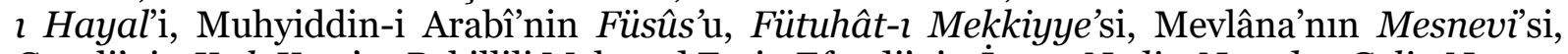
Gazali'nin Kırk Kapı'sı, Bekillili Mehmed Emin Efendi'nin İnsan Nedir, Nereden Gelip Nereye Gidiyor'u, Ahmet Yüksel Özemre’nin Üsküdar'da Bir Attar Dükkânı, vb. 
Romandaki dil ise diğer çağdaş yazarların dilinden özellikle kelime kadrosu itibariyle dikkate değer bir farklılık göstermemektedir. Burada dili özellikli kılan romanın odaklandığı tema nedeniyle metne sızan tasavvufi kelime, kavram, mecaz ve zengin metinler arası ilișki boyutudur. Fakat burada dil konusunda ilginç bir nokta, aşkın gerçekliği ifade vasıtası olarak mevcut dil malzemesini kullanmanın yarattığı güçlüktür. Yazar zaman zaman Mustafa aracılığıyla mevcut dil ile aşkın gerçekliği ifade etmenin zorluğunun sebeplerini açıklamaya çalışır:

Tasavvufi bakış açısına göre varlık âlemi, görünen (reel) ve görünmeyen (sürreel) iki düzlemde tezahür etmektedir. Görünen âlem, sürekli bir değișim hâlindedir. Sürekli değișim ve oluş içindeki bu âlemden, görünmeyen âleme bir yol bulmak gereklidir. Çünkü değişmeyen hakikat o âlemdedir. Görünen âlemdeki her şey, her isim ve her açılama değişmez hakikate giden yolu belirsizleştiren hatta karartan bir "örtü"dür. Örtüyü kaldırınca değişmez hakikati göreceğini, ona yaklaşacağını umarsın ama başka bir şekil ve örtüyle karşılaşırsın. Öyle ki "aralandıkça örtüleri daha çok gizlen"mektedir (s.8). Çelişik bir şekilde, yaşadığımız hayat / görünür âlem, aradığımız değişmez hakikate ulaşmanın hem tek yolu hem de engelidir. Eldeki "tek vasıta" hakikate ulaşmanın ve onun mahiyetini tam olarak anlamanın önünde bir örtüdür: "Neye baksam O. Bin bir giysiyle örtünüyor, bin bir cilveyle belirip belirip gizleniyor.” (s.8). Suretlerin içinde maddi varlığı da bir suretten ibaret olan insan da sürekli bir değişim içindedir. Mustafa "Değişiyorum. Her an başka bir hâle bürünüyorum. Hâlden hâle geçiyorum.” (s.174) derken kendi benliğindeki sürekli değișimin bilincinde olduğunu ifade etmektedir. Değișim, daha iyi olana doğru yol alma çabasıdır. Bu nedenle "her bir yaratık değişim ve akış içindedir. Her bir "Ben” açılma sürecindedir." (Chittick, 2003: 112). Değişken, sabit olmayan suretler, tecelliler her yerde ve her şeydedir. İşte bu sürekli değissimin içinden değişmez öze ulaşmak, ancak ayrı bir anlayışa sahip olanların ulaşabileceği bir hedeftir. Dolayısıyla dil de suretlerden bir suret olarak hakikat yolunda hem vasita hem de engeldir: "Konuştukça O’nu çoğaltıyorum farkındayım. Ama çaresizim, ne yapabilirim? Başka türlü nasıl anlatabilirim?” (s.8); "Anlattıkça dilin nasıl bir örtü olduğunu daha çok hissediyorum.” (s.11); "Hakikat dile gelemez. Gelen hakikatin suretidir. Sir dile dökülemez." (s.25); "Dil örtüdür.” (s.292) gibi pek çok ifade dile dair bu ikilemi ortaya koymaktadır. Dil bağlamında ortaya çıkan bu çelişki hemen hemen bütün mutasavvıfların da ortak bir "sıkıntı ve şikâyet konusu"dur (Kılıç, 2004: 76).

Dil, yolcuların kendilerini ifade etmede (yetersiz de olsa) tek vasitası olduğundan bu yoğun tecrübeyi yazarak dışa vurmaya çalışırlar. Fakat daha önce menzile düssen / varan yolcuların tecrübelerini anlattıkları kitaplar arayışın önüne geçer, hakikate dönüşürse tehlikelidir. $\mathrm{Bu}$ nedenle yolculuğun bir noktasında yolcu bütün kitapları yakması gerektiğini / yazılana itibar etmemesi gerektiğini anlamalıdır: "Bilince kitaplarımı yaktım." (s.8); "Ne salak bir durum. Gerçeği sadece kitaplardan öğreneceğini sanmak. Bilgi arttıkça hantallaşan gövdemi ne çok yormuşum." (s.21); "Kitaplarımı yırt, suya at." (s.25); "Iç̧im kitap çöplüğü.” (s.25). Bu cümleler ironik biçimde tasavvufu çalışma alanı olarak seçmiş bir akademisyenin sadece okumanın kişiyi hiç bir yere vardırmayacağını herkesten daha fazla idrak ettiğinin göstergeleri konumundadır. "Insanlarm hakikate sadece okuyarak ulaşacağına inanmalarından daha hüzünlü bir şey olamaz.” (s.274) cümlesi bu inancın en açık ifadesidir.

Mutasavviflar, mevcut dil ile aşkın gerçekliği ifade etmeyi hedeflediklerinde mevcut dilin kısıtlamalarından kurtulmak için farklı bir üst dil yaratma çabası içinde olmuşlardır. Mutasavvıfların mecazlarla örülü özel bir dil kullanmalarının sebebi de budur. Aşkın gerçekliğin yetersiz olsa da tek mümkün ifade vasıtası olan dili, bu gerçekliği ifadeye uygun ayrı ve neredeyse şifreli bir surete çevirmeye "kuş dili" denir. Kuş dili "göçmenlerin grameri”dir (s.39). Kuş dili bir üst dildir. Aşkın gerçekliğin kendini olabildiğince ortaya koyabileceği, kendine mahsus bir kelime kadrosu olan özel bir dildir bu. Çünkü gündelik dili dolduran kelimeler zaman içinde yavanlaşmış hatta içeriğini kaybetmiştir: "Dil oyundur. Bir tür tuzak. Örtüdür. Gizler; ima ettiğini, en açık biçimde dahi olsa örter. Yorar, yorulur ..." (s.42). Bu nedenle mutasavviflar "Kuşlartn dili der, a'mâk-ı hayal der, başka bir kıllfuydurur, simgeydi, imgeydi, mecazdı derken anlatır bir şeyler." (s.292). Mahmut Erol Kılıç'in ifadesiyle, böylece zaten örtü olan dile mecazlarla örülü -ancak ehlinin nüfuz edebileceği- bir 
başka örtü çekerler. Bu şekilde de bu gerçekliği, nâ-ehlin elinden kaçırırken ehle açık hâle getirirler. (Kılıç, 2004: 120).

İște dilin de içinde bulunduğu, suretlerden oluşan bütün bu örtülerin altında yatan hakikat ise yine "bir"dir. Çünkü her şey "bir"den ibarettir. Bu hakikate yaklaşma ânı, benliğin algıladığı bütün suretlerin (insan, nesne, söz, bellek veya benliği besleyen para / ünvan / eşya / aile gibi her şey) yok olması demektir. Insan ancak suretlerden kendini koparırsa değişmeyen hakikate yani Yaradan’ın gizlendiği "birlik"e ulaşmayı başarabilir.

"O kadar çok ses var ki içimde. O kadar çok görüntü, kitap, yüz, kelime, gölge, korku ve kuşku var ki... O kadar çoğalmışım ki.” (s. 85).

"İşimden ayrıldım. Giysilerimi attım. Kartvizitlerimi yok ettim. Eşimi, çocuklarımı bıraktım. Tutkularım ıslak bir yünden dikenli bir dalın çekilişi gibi gitti. Paramı, vadesi yakın uzak bütün çeklerimi yırtıp attım. Ünvanlarmı unuttum. Telefonu firlattım. Defteri çöpe attım. Hiç bir şeyim kalmamıştı. Sadece dilim vardı, yüzümdeki ifadeler duruyordu. Soluk alp veriyordum, canluydım ama ne istiyor ne biliyor ne görüyor ne de yürüyordum. Her şeyden kopmuştum. Herkesten kaybolmuştum. Belleğim silinmişti. Lekesiz beyaz bir kâ̆ğt gibiydim.” (s. 8-9).

İnsan işte bu suretlerden sıyrılma sürecinde, "birlik"e yöneldikçe hem kendi hem de bütün insanlığın hakikatiyle yüzleşmeye başlar. O yokluğun içinde, o suretler içinde Yaradan'a en yakın şeye yaklaşır: Halife "insan". "Herşey insandı." (s.9) Tabii bu, insanın da sadece bir suret olduğunu algıladıktan sonraki aşamadır.

Yazarın tam da bu anlayışa uygun olarak Mustafa'nın hayatını anlattığını görürüz. Bu anlatım, Mustafa'ya dair her şeyde, özellikle Mustafa'nın yaşamöyküsü içindeki manevi ilerleyişini aktarım sürecinde açıkça karşımıza çıkmaktadır.

Sıradan bir hayat vasıtasıyla anlatılan manevi olgunlaşma süreci romanın ana tematik eksenini oluşturduğundan, kurgu kişilik Mustafa'nın hayatı da tasavvufi bir hayat / varlık inancı üzerinde inşa edilmiştir. Tasavvufi zihniyetin ana kalıplarından yola çıkarak hayatı ve bireyi anlatma çabasının romanın bütün dış yapı unsurlarını klasik anlatım biçiminin dışına çıkmaya zorlamış görünmektedir. Öyle ki, zaman / mekân / kişiler gibi klasik anlatının temel unsurları tespit edilebilir belirginlikte olmakla beraber, alışılanın aksine, aynı zamanda bir karmaşa / düzensizlik izlenimi bırakmaktadır. Fakat yakından bakıldığında bütün bu unsurların tasavvufi hayat algısına paralel bir "gizli düzen"i barındırdığı, bu "karmaşa" yanılsamasının belli bir amaca hizmet ettiği görülebilmektedir.

Dolayısıyla romanda en dikkati çeken unsurlardan ilki, "realist" roman anlayışının insanın dünya ile ilişkisini somutlaştıran zaman / mekân / kişiler gibi birimleri çok önemseyerek birincil konuma çıkardığı gerçeğinin bu romanda göz ardı edilmesidir. Çünkü "realizm"deki hedef, gözün ve aklın algıladığı somut dünyayı mümkün olduğu kadar inandırıcı bir şekilde anlatmaktır. Realist anlayışta da bir içe dönüş, bireyin iç dünyasını anlama çabası görülmekle birlikte bu çaba, daha çok bireyin diş dünya ile etkileşiminden kaynaklanan olumlu / olumsuz izlenimler yığınından ibarettir. Oysa bu romanda, gerçeklik (realite) gerçeküstü (sürreel) evrenin bir izdüşümüdür ve o gerçeküstü evrenle daima etkileşim hâlindedir. Buna göre Mustafa'nın -romanda sık sık yinelendiği üzere- "kendinden kendine yaptığı yolculuk" görünür gerçekliğin ötesindeki gerçeküstü evrenle bağ kurma çabasına dönüşmektedir.

$\mathrm{Bu}$ yolculuğun nihai amacı var olan insanı öldürüp tamamen yeni bir insan yapmaktır: "Burada bir insan binası yıkılıyor. Orada bir insan binası yapılıyor." (s.33). İște bu nedenle yani eski insanı yok etmek anlaminda -hemen hemen bütün tasavvufi metinlerde- "ölmeden ölmek", "nefsi kurban etmek" gerektiğinin altı çizilir. Bu, mevcut benliği öldürmek demektir. Ölmeden ölmek ifadesi ironik biçimde tam bir uyanışı ve dirilişi de işaret etmektedir. "Insanlar uykudadır ölünce uyanırlar.” (s.22) hadisi de bu dirilişi vurgulamaktadır. İşte bu yeni insan 
ve yeni insanın "birlik"le kopmayan teması, yazarın çağdaş insana tüm huzursuzluklarının ilacı olarak sunduğu öneridir.

İfade edildiği üzere romanın en ilginç yönlerinden biri çağdaş gündelik hayat içinden ilahi hakikate yol bulma çabasının anlatılmasıdır. Mustafa ile okur çağdaştır. Mustafa'nın hayata ve topluma dair zihnini dolduran her şey okurun da hayatının bir parçasıdır. Bu durum okura, örtük biçimde benzer bir arayışa ihtiyaç duyup duymayacağı sorusunu sordurmaktadır. Hatasız tertemiz bir çevreden, hatasız bir insan yola revan olmamıştır. Herkesinki kadar sıradan bir hayata sahip olan Mustafa yola çımıștır. Mustafa okurla benzer bir nesneler, duygular ve düşünceler içinden yani sürekli değișen suretler karmaşasından, değișmeyen öze ulaşma sevdasına düşmüştür. Böylece yazar tasavvufu bir öneri olarak öne çıarmaktadır.

Mustafa da okur gibi bu karmaşadan istese de fazla uzaklaşamamaktadır. Yazar bu durumu, yani gündelik hayatın hem Mustafa'yı hem de bütün toplumu etkileyen olay ve durumlarının sel olup akışını özellikle televizyon vasıtasıyla vermeyi sevmektedir. Çünkü suretlerin / tecellilerin çokluğu ve değişkenliği herhâlde en çok bu devirde ve televizyon vasıtasıyla hissedilmektedir:

\begin{abstract}
"Bir traktör homurtusu geliyor sonra. Keşif uçuşu yapan askerî helikopterin gürültüsü... Telefon çalyyor. Küçük kız giriyor odaya, televizyonu açıyor. Cnbc-e’deki filmde kadın bağırıyor. Adama ağız dolusu küfrediyor. Kuzeni ve karısı araya giriyor. Kadının savurduğu yumruk ıskalayınca kapının camın indiriyor. Bileğinden kan fişkırıyor. Bir yarasa firlıyor camdan içeri. Duvara çarpıyor. Kanı ve kokusu beyazcamdan içeri yayılıyor. Uyanıyorum. Telefonun alarmı korkunç. Pencereyi açıyorum. Hava cam gibi. Sis kalkmış. Mükemmel bir gün. Arada hiç bir put yok. Saf, ağırlıksı, şeffaf bir yer burası. Şimdi böyle. Az sonra n'olur bilemem. Ama şimdi kusursuzsun. Seni öyle biliyorum.” (s.13).
\end{abstract}

Temas edilen, irtibata geçilen hayatlar bilgisayar ve televizyon vasitasıyla hat safhaya ulaşmıştır. "Deniz"in yani değişmeyen özün / vahdetin yüzeyde bu kadar dalgalandığı bir devir olmamıştır. Dolayısıyla bu devrin manevi arayış içindeki bireyleri, belki de en çok mücadele vermesi gerekenlerdir. Kendilerini kenara çektiklerinde dahi başka hayatlar, bütün toplum hatta bütün dünya bilgisayar veya televizyon denilen yansitıcılar aracilığıla sel gibi evlere, odalara dolmaktadır. Bu yüzden Mustafa yapayalnız otururken ya da uykudayken bile sık sık televizyon sesine uyanır yani kendinden diş dünyaya / tecelliler deryasına dalar.

Yazar dünyanın bu amansız saldırısını bilhassa izlenimler yığını hâlinde sunmayı sevmektedir. Romanda Youtube, Facebook, internet, radyoda türkü söyleyen Neșet Ertaş, Yurttan Sesler Korosu, Ülkücülerle Devrimcilerin Savaşı, Şükran Ay'ın okuduğu Sevda Yüklü Kervanlar şarkısı, Laguna ile Toyota'nın çarpışması, seksen darbesi, Teoman'ın İstanbul'da Sonbahar şarkısı, Aliya İzzetbegoviç, öğrencilerin sorunları, Marx, Leonard Cohen gibi ardışık olmayan olaylar, kişiler, nesneler tıpkı hayattaki gibi peş peşe, süratle, bir yığın hâlinde Mustafa'nın hayatı üzerinden okura yöneltilir. Zaten Mustafa ile çağdaş olan okur da aynı yığının altında boğulmaktadır.

\begin{abstract}
"Akşam ne çabuk oluyor. Sabah okula geliyorum. Taşıtlar, trafik yoğunluğu öğretim üyeleri, öğrenciler, fakülte çalş̧anları, merdivenler, odalar, koridorlar, kâğıtlar, evraklar, telefonlar, kitaplar, divanlar, mesneviler, menaknnameler, kelimeler, terkipler, dersler akşam oluyor. Zamanı unutmuşum. Günahı da. Otuz yıldır günah sözcüğünü unutmuşum. Zihnimden silinmiş. Hep O’nunlayım.” (s.117).
\end{abstract}

Bu nedenle romanda dış dünya “ahlâksızhklar, kötülükler, zulümler”le (Kabaklı, 2002: 685) beraber, yani olanca hakikatiyle de sergilenmektedir.

$\mathrm{Bu}$ yolculuğun kişinin bu karmaşadan sıyrılıp kendine / kendi hakikatine varması amacıyla yapıldığ 1 "Kendinden kendinedir yolcusu." (s.78) cümlesiyle beraber defalarca yinelenir durur. Kişi, işte bu selden kurtulmak için kendine dönmektedir. Bu yolculuğun içe yöneliş olduğunu 
kuvvetle vurgulamak amacıyla "kalbine doğru bükülmek", "içine bükülmek”, "içine gömülmek" ifadeleri de sıklıkla tekrarlanmaktadır.

\section{Sonuç}

İnsanı, tam olma duygusuna ulaştıracak olan nihai amaç "vahdet” olduğundan, Mustafa çocukluğundan itibaren sürekli olarak kelime-i tevhidi zikreder. Çünkü tevhit, vahdete çıkan yoldur. Birliği ikrardır. Nihai amaç var olan kusurlu benliği yıkmak, yerle bir etmek ve bu enkazın üzerine sapasağlam bir bina inşa eder gibi yepyeni bir insan var ederek vahdete ulaşmaktır. Nitekim Mustafa mürşidi için "Beni bir ev gibi inşa ediyor.” (s. 271) derken yıkılıp yapılan yeni insanı işaret eder.

Vahdet, tasavvufta "deniz"le simgelenir. Mustafa roman boyunca kelime-i tevhit ile kalp kapılarını açmaya çalıştıkça, rüyalarında "deniz" görür, denize dalar veya denizde bir damla olur. $\mathrm{Bu}$, birliğe doğru yol aldığının sembolik göstergeleridir. Bu nedenle roman "birdenbire"nin izahiyla başlar, "birdenbire" ile biter. Romanın sonunda Mustafa'nın arayışının tamamen bittiğine dair bir işaret yoktur. "Bir"e doğru yolculuk daimîdir.

\section{Kaynakça}

Chittick, W. (2003). Tasavvuf / Kısa Bir Giriş, Çev: Turan Koç, İstanbul: İz.

Harmancı, A.; Köseoğlu, A. (2012). "Sadık Yalsızuçanlar'la Şehirler ve Kitaplar Üzerine / Hayat Bir Yolculuktur”, K Dergisi, Temmuz-Ağustos-Eylül 2012, s.20-27.

Kabaklı, A. (2002). "Sadık Yalsızuçanlar”, Türk Edebiyatı, V. 10. Basım, İstanbul: Türk Edebiyatı Vakfı.

Kılıç, M. E. (2004). Sûfì ve Şïr / Osmanl Tasavvuf Şïrinin Poetikası, 3. Basım, İstanbul: Insan.

Uludağ, S. (2012). Tasavvuf Terimleri Sözlüğü, İstanbul: Kabalcı.

Yalsızuçanlar, S. (2012). Birdenbire, İstanbul: Timaş.

Yalsızuçanlar, S. (2000). “Öykü Soruşturması”, Hece / Türk Öykücülüğü Özel Sayısı, 46 / 47 (Ekim / Kasım 2000), s.261-262. 